\title{
ARTICLES
}

Submitted 03.14.2016. Approved 10.13.2016

Evaluated by double blind review process. Scientific Editor: Ricardo Rochamn

DOI: http://dx.doi.org/10.1590/So034-759020170204

\section{RELATIONSHIP BETWEEN AUDITORS' FEES AND EARNINGS MANAGEMENT}

\author{
Relação entre a remuneração dos auditores e o gerenciamento de resultados \\ contábeis
}

\author{
Relación entre la remuneración de los auditores y la gestión de resultados \\ contables
}

\begin{abstract}
This study investigates the relationship between audit fees and earnings management in the Brazilian market. In response to the research question, we used a sample of 300 firms listed on the BM\&FBovespa for which it was possible to identify the amount paid to the auditors, using data gathered from the Economatica ${ }^{\circ}$ database and the website of the Brazilian Securities Commission (Comissão Brasileira de Valores Mobiliários [CVM]). We analyzed the regressions with the aim of supporting or refuting the hypothesis that audit firms that charge less for their service tend to be more relaxed regarding earnings management by their client companies. The results support this hypothesis. The main contribution of this study is the possibility of stating that more aggressive earnings management occurs predominantly among firms that pay less than expected for audit services. This study evidences the perception of risk by audit firms and how this is reflected in the audit fees charged.
\end{abstract}

KEYWORDS | Auditors, audit fees, audit quality, audit services, earnings management.

\section{RESUMO}

Este artigo investiga a relação entre a remuneração dos auditores e o gerenciamento de resultados no mercado brasileiro. Para responder à pergunta de pesquisa usamos uma amostra de 300 empresas listadas na BM\&FBovespa, nas quais se identificou o valor pago para os auditores, usando dados da Economática ${ }^{\circledR}$ e do site da Comissão Brasileira de Valores Mobiliários (CVM). Analisamos as regressões com o objetivo de confirmar ou refutar a hipótese de que as empresas de auditoria que cobram menos que o esperado pelo serviço, tendem a ser mais perniciosas em relação ao gerenciamento de resultados de seus clientes. Os resultados confirmam esta hipótese. A principal contribuição é afirmar que o gerenciamento de resultados agressivo ocorre predominantemente entre as empresas que pagam menos do que o esperado pelos serviços de auditoria. Este estudo evidencia a percepção do risco pelas empresas de auditoria e como isso se reflete na remuneração dos auditores. PALAVRAS-CHAVE / Auditores, remuneração de auditores, qualidade de auditoria, serviços de auditoria, gerenciamento de resultados.

\section{RESUMEN}

\section{ANTONIO LOPO MARTINEZ}

lopo@fucape.br

Professor at Fundação Instituto

Capixaba de Pesquisas em

Contabilidade, Economia e Finanças

- Vitoria - ES, Brazil

\section{ARQUIMEDES DE JESUS MORAES}

arquimedes.moraes@gmail.com Professor at Universidade Vila Velha, Departamento de Graduação em Ciências Contábeis - Vila Velha Espírito Santo, Brazil
En este trabajo se investiga la relación entre la remuneración de los auditores y los resultados de la gestión en el mercado brasileño. Para responder a la pregunta de investigación se utilizó una muestra de 300 empresas que figuran en la BM \& F Bovespa, en el que se identifican la cantidad pagada a los auditores, con datos de Economática $\circledR_{\text {y }}$ el sitio de la Comisión de Valores Mobiliarios (Comissão Brasileira de Valores Mobiliários [CVM]). Analizamos las regresiones con el fin de confirmar o refutar la hipótesis de que las sociedades de auditoría que cobran menos de lo esperado por el servicio, tienden a ser más perjudicial en relación con la gestión de los ingresos de sus clientes. Los resultados confirman esta hipótesis. La principal contribución es decir que la gestión de los ingresos agresiva se produce predominantemente entre las empresas que pagan menos de lo esperado por servicios de auditoría. Este estudio muestra la percepción de riesgo por parte de las empresas de auditoría y cómo esto se refleja en la remuneración de los auditores.

PALABRAS CLAVE | Auditor, remuneración de los auditores, calidad de auditoria, servicios de auditoría, gestión de resultados 


\section{INTRODUCTION}

This study investigates the relationship between auditors' fees and earnings management in Brazil. This is relevant, since other studies have shown that the total remuneration paid to independent auditors is associated with firms' performance (Hay, Knechel, \& Wong, 2006; Stanley, 2011). Researchers such as Kinney and Libby (2002) and Eshleman and Guo (2013) have also examined the effects of audit fees on the quality of the services rendered.

More specifically, we empirically examine the relationship between audit fees and the quality of audit services-measured as the competence to prevent earnings management-rendered to the 300 largest firms listed on the BM\&FBovespa in the period between 2009 and 2012. We obtained the data from the financial statements contained in the Economatica ${ }^{\circledR}$ database and the site of the Brazilian Securities Commission (Comissão de Valores Mobiliários [CVM]).

The fees paid for audit services can be used as a proxy for the quality of the services provided by audit firms (Hallak \& Silva, 2012). One of the ways to measure audit quality is permissiveness of the auditor with respect to earnings management. In this context, our research question is as follows: does the size of the audit fees influence auditing quality?

This question is still an open one in the Brazilian literature. Indeed, very few studies pertaining to this issue have been published in the literature in general. The issue is of particular interest due to the particularities of the Brazilian institutional setting relative to the United States, with the main difference being the weaker monitoring of audit quality in Brazil.

Among the differences in rules between the countries are the structure and status of the board of directors (Porta, LopezFlorencsio, Shleifer, \& Vishny, 1998). In practical terms, board members would like yardsticks to measure the effects of the remuneration offered to auditors, as can be seen in the works of Porta, Lopez-Florencsio, Shleifer, and Vishny (1997) and Porta et al. (1998).

To analyze our research question, we develop three models. The first aims to identify the determinants of auditors' compensation in Brazil. After estimating these variables, we compute the magnitude of earnings management of a given firm in a year using discretionary accruals. After defining the metrics for auditor compensation and audit quality, we contrast them to identify if any perceptible relationship exists. We were particularly interested in studying if an abnormal low audit fee would be associated with a higher propensity to income-increasing earnings management.

The rest of this paper is organized as follows. Next, we review the relevant literature, followed by a presentation of the methodology in section three. We present and discuss the results in section four, before concluding in section five.

\section{AUDIT FEES AND EARNINGS MANAGEMENT}

As mentioned in the introduction, the aim of this study is to investigate whether the fees paid to auditors influence audit quality. In this section, we review the main determinants of audit quality and analyze the contributions from the literature on earnings management in an attempt to understand how audit fees are related to quality.

The first studies in Brazil covering audit fees date to the $1980 \mathrm{~s}$ (Hallak \& Silva, 2012). Among the pertinent aspects of auditing is the independence of the audit firms. Without independence, the probability of biased findings will obviously be higher (Braunbeck, 2010). For example, audit firms that also render nonaudit consulting services to their clients might be more willing to overlook accounting shortcomings for fear of losing the additional consulting fees. In addition, audit firm tenure can affect the quality of the service, as auditors become more personally involved with managers and less likely to be critical of poor accounting practices. Both these potential problems have been addressed by regulators in most countries in recent years, by establishing rules on separation of auditing from consulting and by mandatory auditor rotation.

Regarding fees, researchers have been curious for some time regarding the effects of audit fees on the quality of the services rendered. The more independent audit firms tend to compete to offer personalized services that add value to the client, and can charge higher fees for better quality services (Francis, 1984). In short, audit fees can be used as a metric of the quality of the service (Hallak \& Silva, 2012). Hence, it is not enough for the auditor to have expertise; it must also be independent (Deangelos, 1981; Watts \& Zimmerman, 1986).

However, higher fees do not necessarily mean stronger scrutiny from the auditor, and hence better audit quality. While some studies have indicated that higher fees translate into stronger commitment and more competent services and that, on the other hand, lower fees mean poorer quality, other researchers have argued that higher fees can cause the auditor to lose independence, resulting in more biased audit findings (Eshleman \& Guo, 2013). Evidence in this respect was found by Kinney and Libby (2002), indicating that higher (abnormal) audit fees could denote illicit acts by the company and inflated future earnings.

An early study by Defond, Raghunandan, and Subramanyam (2002) did not find symmetry between abnormal audit fees and auditing quality, while later works did find a relationship in this respect, indicating that higher (abnormal) audit fees are associated with greater discretionary accruals by the client firm (Choi, Kim, \& Zang, 2010). This is in line with the argument that higher fees tend to lead to a loss of auditor independence, and hence produce a more biased opinion of the client's accounting practices (Eshleman \& Guo, 2013). Asthana and Boone (2012) found similar evidence regarding the economic dependence of the auditor on the client. In 
their sample, they noted that clients that spent more on auditing had higher discretionary accruals, mainly for meeting analysts' projections.

Asthana and Boone (2012) employed a model to shed light on the fee-quality relationship depending on the signal sent by audit fees. In turn, Gupta, Krishnan, and Yu (2012) analyzed whether auditors tolerate earnings management when audit fees are low, to examine the relationship between abnormally low audit fees and fraudulent financial statements. Finally, Choi et al. (2010) considered the total value of discretionary accruals to be a proxy of the effectiveness of auditing services.

Junjian and Dan (2015) provided evidence that audit fees reflect risk differences across litigation regimes. In their research using a sample of Japanese firms cross-listed in U.S. markets, they find that there is a difference in audit fees under different litigation environments, and that audit fees increase with higher litigation risk. They also documented that high earnings management risk is correlated with high audit fees, and that audit fees originated from earnings management risk is reduced under a greater litigation risk environment.

Other interesting research on the topic is from Bryan and Mason (2016). They investigated whether sudden and severe reductions in total CEO compensation affect auditor perceptions of risk, and documented that extreme CEO pay cuts can incentivize the CEO to manipulate the financial reports or to make risky operational decisions in a desperate attempt to improve firm performance. This incentive, in turn, is likely to impact auditor assessments of audit risk and auditor business risk, leading to higher audit fees.

In our research, we investigate the relationship between audit fees and audit quality with the models of Gupta et al. (2012), adapted to Brazilian conditions, with earnings management serving as a proxy for audit quality. More specifically, we test the hypothesis that abnormal audit fees create a setting that is more propitious for earnings management-in a more specific way, whether an abnormal low audit fee stimulates income-increasing earnings management.

\section{METHODOLOGY}

In this part, we present the research method, the sample, and the data analysis techniques, including the model used to determine the audit fees and the model developed to explain earnings management as a function of abnormal audit fees.

\section{Research method}

The aim of this study is to investigate whether the compensation of independent auditors influences the quality of their services, by applying quantitative statistical techniques to the data gathered, and by calculating simple statistics such as percentages, means, and standard deviations and applying these in correlation and regression analyses (Richardson, 2010). This study is descriptive in nature, as defined by Barros and Lehfeld (2000), seeking "to discover the frequency with which a phenomenon occurs, its characteristics, causes, relations and connections with other phenomena" (p. 70). More specifically, our aim is to discover and classify the relationship and causality between variables that measure phenomena. The data were obtained from the site of the Brazilian Securities Commission (CVM) and the Economatica ${ }^{\circledR}$ database.

\section{Sample}

The initial sample consisted of 566 firms listed on the BM\&FBovespa in the period between 2009 and 2010, for which it was possible to identify the amount paid to the independent auditors. However, we observed that many of them did not have a proper profile for inclusion in the study. Therefore, we narrowed the sample down to the 300 largest firms, as measured by year-end market value, for a total of 1,200 observations. After transforming the data, we organized the variables for panel analysis to investigate the behavior of each firm over time.

\section{Data collection technique}

The data are secondary. Those related to auditors were gathered from the CVM site, while the accounting data were obtained from the Economatica ${ }^{\circledR}$ database. In the former case, our interest is the amount of audit fees. This information is contained in Section 2 ("Independent Auditors") of the Reference Form (Formulário de Referência [FR]) that all listed companies must file annually with the CVM. These data on audit fees are segregated by type of service. In turn, the Economatica ${ }^{\circledR}$ database contains an extensive collection of the standard data on Brazilian firms based on their published financial statements. Here we use the following variables to compose the models: market value, current assets, long-term assets, total assets, current liabilities, long-term liabilities, total liabilities, stockholders' equity, liabilities + stockholders' equity, gross revenue, net income, EBIT (earnings before income tax), and EBTIDA (earnings before income tax, depreciation and amortization).

\section{Data analysis techniques}

Based on the theoretical framework, we formulated the models and analyzed the corresponding regressions by using the Eviews econometric software, with application of the control variables identified. These models are those used by Gupta et al. (2012), 
adjusted to the Brazilian market reality. The three models are presented below. The first two are estimated by ordinary least squares (OLS) and the third by logistic regression.

\section{Model 1 - Determinants of auditor compensation}

In this section, we set out a model formulated to explain earnings management, based on multiple observations of characteristics of consumers of auditing services, in light of the specialized studies of Sinumic (1980), Firth (1997), Ashbaugh, Lafond, and Maythew (2003), and Sankaraguswamy and Whisenant (2009).

With respect to the models developed by Gupta et al. (2012), we adapt the model to the Brazilian reality by using 12 of their 23 variables to determine audit fees. Therefore, we use the following equation employing panel data, where $B_{o}$ denotes the intercept, $\varepsilon$ is the error term, and the other variables are as defined in Exhibit 1.

$$
\begin{aligned}
\text { AFEE }_{i t}= & \beta_{0}+\beta_{1} B_{I G} 4_{i t}+\beta_{2} L_{T A_{i t}}+\beta_{3} \text { MTB }_{i t}+\beta_{4} L_{E V}+\beta_{5} R O A_{i t} \\
& +\beta_{6} \text { ARINV }_{i t}+\beta_{7} \text { TENURE }_{i t}+\beta_{8} \text { SEGMENT }_{i t}+\beta_{9} L A G E \\
& +\beta_{10} \text { FULL_IFRS }_{i t}+\beta_{11} \text { CORPGOV }_{i t}+\varepsilon_{i t}
\end{aligned}
$$

\begin{tabular}{|c|c|}
\hline Variables & Data Source \\
\hline $\begin{array}{l}\text { AFEE } \\
\text { Natural log from audit fees }\end{array}$ & CVM \\
\hline $\begin{array}{l}\text { BIG4 } \\
\text { Equals } 1 \text { if a firm is audited by Deloitte \& Touche, Ernst \& Young, KPMG, P\&W }\end{array}$ & CVM \\
\hline $\begin{array}{l}\text { LTA } \\
\text { Natural log of total assets at end of fiscal year }\end{array}$ & Economática \\
\hline $\begin{array}{l}\text { MTB } \\
\text { Market-to-book index defined as market value of stocks divided by book value of equity }\end{array}$ & Economática \\
\hline $\begin{array}{l}\text { LEV } \\
\text { Total Asset less equity divided by total asset }\end{array}$ & Economática \\
\hline $\begin{array}{l}\text { ROA } \\
\text { Net profit divided by total assets }\end{array}$ & Economática \\
\hline $\begin{array}{l}\text { ARINV } \\
\text { Receivables and Inventories divided by total assets. }\end{array}$ & Economática \\
\hline $\begin{array}{l}\text { TENURE } \\
\text { Time of using the same Auditor firm in years }\end{array}$ & CVM \\
\hline $\begin{array}{l}\text { SEGMENT } \\
\text { Number of segments in the business }\end{array}$ & CVM \\
\hline $\begin{array}{l}\text { LAGE } \\
\text { Natural log of the age of the enterprise. }\end{array}$ & CVM \\
\hline $\begin{array}{l}\text { FULL_IFRS } \\
\text { Equals o for } 2009,1 \text { any other year after }\end{array}$ & Economática \\
\hline $\begin{array}{l}\text { CORPGOV } \\
\text { Equals } 1 \text { if the enterprise is listed in the special corporate governance segment, and o otherwise. }\end{array}$ & CVM \\
\hline
\end{tabular}

Exhibit 1. Definition of the variables (Model 1)

Note: This exhibit presents the definition of the variables and the source of the data for Model 1 - Determinants of Auditor Compensation.

\section{Model 2 - Performance-adjusted discretionary accruals}

As a measure of earnings management, we rely on the model of Kothari, Leone, and Wasley (2005)-which is the model of Jones adjusted by performance-to estimate abnormal discretionary accruals. Abnormal accruals have been used by many authors as a metric for earnings management (e.g., Ashbaugh et al., 2003; Becker et al., 1998; Larcher \& Richardson, 2004).

Martinez (2013, p. 9) pointed out that Kothari et al. (2005) proposed an adjusted improved model to detect discretionary accruals in Brazil, controlling the calculation of discretionary accruals with firms in a single group and in comparison with performance.

This model has the following formulation: 


$$
\begin{aligned}
T A_{i t}=\beta_{0}+\beta_{1}\left(\frac{1}{A S S E T_{i, t-1}}\right)+\beta_{2}\left(\triangle V_{E N D A S_{i t}}-\right. & \left.\Delta \mathrm{AR}_{i t}\right)+\beta_{3} \mathrm{NCA}_{i t} \\
+ & \beta_{4} \mathrm{ROA}_{i, t-1}+\varepsilon_{i t}
\end{aligned}
$$

where $B_{o}$ is the intercept, $\varepsilon$ is the error term and the other variables are as defined in Exhibit 2.

\section{Exhibit 2. Definition of the variables (Model 2)}

\begin{tabular}{l|c}
\hline Variable & Data base \\
\hline $\begin{array}{l}\text { TA } \\
\text { Total Accrual, computed as Earnings before extraordinary items less cash flow from operations scaled by total assets }\end{array}$ & Economática \\
\hline $\begin{array}{l}\Delta \text { SALES } \\
\text { Variation on sales between last year and current year, scaled by total assets; }\end{array}$ & Economática \\
\hline $\begin{array}{l}\Delta \text { AR } \\
\text { Variation in accounts recievable between last year e curent year, scaled by total assets; }\end{array}$ & Economática \\
\hline $\begin{array}{l}\text { NCA } \\
\text { Non current assets from current year scaled by total assets from previous year; }\end{array}$ & Economática \\
\hline $\begin{array}{l}\text { ROA_(it-1) } \\
\text { Return on assets computed as earnings before extraordinary items divided for total assets. }\end{array}$ & Economática \\
\hline
\end{tabular}

Note: This exhibit presents the definition of the variables and the source of the data for Model 2 - Performance adjusted discretionary accruals.

\section{Model 3 - Determinants of earnings management}

The third and last model measures whether or not there is a relationship between abnormal audit fees and earnings management. Following Gupta et al. (2012) - again with adaptations to the Brazilian market-we use 11 variables to estimate the following model with panel data:

$$
\begin{gathered}
\text { DAC }_{i t}={ }_{0}+{ }_{1} \mathrm{NABAFEE}_{i t}+{ }_{2} \mathrm{NONAUDIT}_{-} \mathrm{FEES}_{i t}+{ }_{3} \mathrm{BIG}_{i t}+{ }_{4} \mathrm{LMV}_{i t} \\
+{ }_{5} \mathrm{MTB}_{i t}+{ }_{6} \mathrm{LEV}_{i t}+{ }_{7} \text { LOSS }_{i t}+{ }_{8} \mathrm{CFO}_{i t}+{ }_{9} \mathrm{OPCYCLE}_{i t}+ \\
{ }_{10} \mathrm{VOLCFO}_{i t}+{ }_{11} \mathrm{VOLSALE}_{i t}+{ }_{12} \text { Full_IFRS }_{i t}+{ }_{13} \mathrm{CORPGOV}_{i t}+{ }_{i t}
\end{gathered}
$$

where $B_{o}$ is the intercept, $\varepsilon$ is the error term and the other variables are as defined in Exhibit 3.

\section{Exhibit 3. Definition of the variables (Model 3)}

\begin{tabular}{l|c}
\hline Variables & Data Source \\
\hline $\begin{array}{l}\text { DAC } \\
\text { Discretionary accrual computed using model (2); where } 1 \text { indicates income increasing earnings manage }\end{array}$ & Error from Model 2 \\
\hline $\begin{array}{l}\text { NABAFEE } \\
\text { Equal } 1 \text { if abnormal audit fees (err from model 1) is negative and zero otherwise; }\end{array}$ & Error from Model 1 \\
\hline $\begin{array}{l}\text { NONAUDIT FEES } \\
\text { Equal } 1 \text { if there is nonaudit fees paid to auditor and zero otherwise. }\end{array}$ & CVM \\
\hline $\begin{array}{l}\text { BIG4 } \\
\text { Equal } 1 \text { if a firm is audited by Deloitte \& Touche, Ernst \& Young, KPMG, Pricewater }\end{array}$ & CVM \\
\hline $\begin{array}{l}\text { LMV } \\
\text { Natural log of market value of stock at end of fiscal year. }\end{array}$ & Econononatica \\
\hline $\begin{array}{l}\text { LOSS } \\
\text { Equal } 1 \text { if a firm reported loss in the current year, and o otherwise. }\end{array}$ & Economática \\
\hline $\begin{array}{l}\text { CFO } \\
\text { Cash flow from Operations scaled by total assets; }\end{array}$ & Economática \\
\hline $\begin{array}{l}\text { OPCYCLE } \\
\text { Natural log of operational cycle days }\end{array}$ & Economática \\
\hline $\begin{array}{l}\text { VOLCFO } \\
\text { VOLSALA } \\
\text { Standard deviation of sales scales by assets from year t-4 to year t; }\end{array}$ & CVM \\
\hline
\end{tabular}

Note: This exhibit presents the definition of the new variables (not included in Model 1) and the source of the data for Model 3 - Determinants of earnings management. 


\section{ANALYSIS OF THE RESULTS}

In this section, we present the results of each model, starting with analysis of the data through descriptive statistics and the correlation matrices of the variables.

\section{Descriptive statistics}

The descriptive statistics of some variables included in equations (1) and (3) are presented in Tables 1 and 2, respectively.

Table 1. Descriptive statistics (Model 1)

\begin{tabular}{|c|c|c|c|c|c|}
\hline Variables & Mean & Median & S.D. & $25 \%$ & $75 \%$ \\
\hline AFEE & 2.6489 & 2.6117 & 0.6038 & 2.2765 & 2.9731 \\
\hline LTA & 3.4658 & 3.4658 & 0.7781 & 2.9337 & 3.9891 \\
\hline MTB & 1.2558 & 1.4507 & 24.6138 & 0.8241 & 2.5352 \\
\hline ROA & 0.0402 & 0.0346 & 0.1330 & 0.0076 & 0.0727 \\
\hline ARINV & 0.3776 & 0.2879 & 0.3639 & 0.1279 & 0.5057 \\
\hline TENURE & 2.8866 & 2.0000 & 2.4982 & 1.0000 & 4.0000 \\
\hline SEGMENT & 2.6285 & 1.0000 & 3.4761 & 1.0000 & 2.7500 \\
\hline
\end{tabular}

Note: This table presents the descriptive statistics of the variables included in Model 1.

In the descriptive statistics of equation (1), the mean natural logarithm of the audit fees paid is 2.65 . As can be seen in Table 1 , most of the observations (firm-year) involved auditing by one of the Big 4, as can be noted by the average of this binary variable, which is $82.51 \%$. The binary nature is rooted in the occurrence or not of a defined event, namely being audited by one of the Big 4 independent audit firms. The average auditor tenure is 2.88 years and the average age of the audited companies is 35 years, while the number of days between the end of the fiscal year and the announcement of the financial statements is 78 days.

Table 2. Descriptive statistics (Model 3)

\begin{tabular}{|c|c|c|c|c|c|}
\hline Variables & Average & Median & S.D. & $25 \%$ & $75 \%$ \\
\hline DAC & 0.1497 & 0.0000 & 0.3569 & 0.0000 & 0.0000 \\
\hline NABAFEE & 0.4591 & 0.0000 & 0.4986 & 0.0000 & 1.0000 \\
\hline NONAUDIT_FEES & 0.3642 & 0.0000 & 0.4814 & 0.0000 & 1.0000 \\
\hline $\mathrm{BIG}_{4}$ & 0.8251 & 1.0000 & 0.3800 & 1.0000 & 1.0000 \\
\hline LMV & 0.7831 & 0.8811 & 0.7247 & 0.5483 & 1.1515 \\
\hline LOSS & 0.3367 & 0.0000 & 0.4728 & 0.0000 & 1.0000 \\
\hline CFO & 0.0555 & 0.0550 & 0.1489 & 0.0027 & 0.1060 \\
\hline OPCYCLE & 2.0890 & 2.0876 & 0.4243 & 1.8708 & 2.3010 \\
\hline VOLCFO & 0.0499 & 0.0286 & 0.1298 & 0.0158 & 0.0507 \\
\hline VOLSALE & 0.0455 & 0.0216 & 0.1109 & 0.0096 & 0.0475 \\
\hline
\end{tabular}

Note: This Table presents the descriptive statistics of the variables included in Model 3. 
In the descriptive statistics of equation (3), the mean of discretionary accruals is approximately $15 \%$. The percentage of firms that reported a loss in the current year is $33 \%$, and of these, about $46 \%$ made payments for consulting (nonaudit) fees as well as for audit services. The natural logarithm of the year-end market value of the firms is 0.7831 .

\section{Regression analysis}

In this section we present and analyze the results obtained from the regressions of models (1) and (3), which are reported in sections $a$ and $b$ of Table 3, respectively.

\section{Determinants of audit fees}

With respect to the model for the determination of auditors' compensation, the results in Table 3 indicate that the model has predictive power of approximately $54.02 \%$, and of $54.87 \%$ when including controls for the seven main economic segments.

From this table, we can highlight that the variables $\mathrm{BIG}_{4}$, CHANGE_AUD, CORPGOV, LTA, SEGMENT, TENURE, and LAGE are significant according to the t-statistic at $1 \%$ and $5 \%$. The coefficients show a positive relation between $\mathrm{BIG}_{4}$ and the natural logarithm of audit fees, as well as with the natural logarithm of total assets. The variables that are negatively correlated with audit fees are the age of the audited firm and a change in the auditing firm, indicating an inverse relationship with audit fees.

Table 3 (Section A) shows a positive correlation between $\mathrm{BIG}_{4}$ and the amount of audit fees paid, indicating that the Brazilian branches of the four largest audit firms tend to charge higher fees than their smaller peers. There is also a positive correlation between audit fees and the size of the audited company (natural logarithm of year-end assets - LTA). This is understandable, because larger firms on average require more work by the auditor due to their greater complexity and volume of data.

The MTB variable is positively correlated with audit fees. A possible explanation is that firms with higher market than book value tend to be exposed to more risk, requiring a more thorough analysis by auditors, and commensurately higher feesbut not significantly so. The variable LEV is also positively (but not significantly) correlated with audit fees.

ARINV is positively and significantly correlated with audit fees. An explanation for this result is that auditors have to work harder to examine the accounts of firms with higher accounts receivable and inventories, due to the need for more tests of the creditworthiness of customers and more inventory counts.

The positive correlation with the TENURE variable is surprising because it indicates that the longer the relationship lasts between a firm and its auditors, the more the latter tend to charge for their services. One possible explanation of the contrary is that when you change auditors, you may be looking for less expensive audit fees.

The SEGMENT variable is significant, meaning that the greater the number of business segments in which a company operates, the more the auditor tends to charge. Company age has a negative sign, indicating that older firms are more consolidated, tending to pose a lesser challenge to their auditors; the lower risk means auditors can charge less. In contrast, newer companies have more uncertainties, with higher risk, possibly prompting auditors to charge more.

\section{Determinants of earnings management}

In relation to the determinants of earnings management, used here as an inverse proxy for audit quality, the $\mathrm{R}^{2}$ values in Table 3 (section B) show that the model has predictive power of approximately $45.00 \%$.

With respect to the results of Table 3, the NABAFEE variable stands out. It is highly significant, indicating that firms that pay their auditors less than expected or below normal tend to manage earnings more. This confirms that auditors that charge less tend to be more tolerant of earnings management by their clients.

The variable representing fees for consulting (nonaudit) services has a positive coefficient, indicating that firms that render nonaudit services are more likely to be tolerant of earnings management by their clients, but the results are not significant. In this context, we cannot state that the offer of nonaudit fees by auditors compromise audit quality in the Brazilian audit market. However, the sign raises some doubts, requiring future research on this issue.

With respect to the control variables, LOSS stands out: the greater the loss suffered, the lower the probability of aggressive earnings management to boost income. In other words, companies that suffer losses do the opposite of using discretionary accruals to minimize the losses, so that the results will look comparatively better in the following period. This is in line with the "take a bath accounting" hypothesis.

The cash flow variable is negatively correlated with earnings management, indicating that companies with higher cash flow feel less compelled to manage earnings, while those with lower cash flow tend to manage earnings more aggressively.

The operational cycle variable is not significant, but sales volatility is, indicating that companies whose sales have greater seasonal variability tend to use discretionary accruals more aggressively to smooth income. 
Table 3. Regression results - Model 1 (Section A) and Model 3 (Section B)

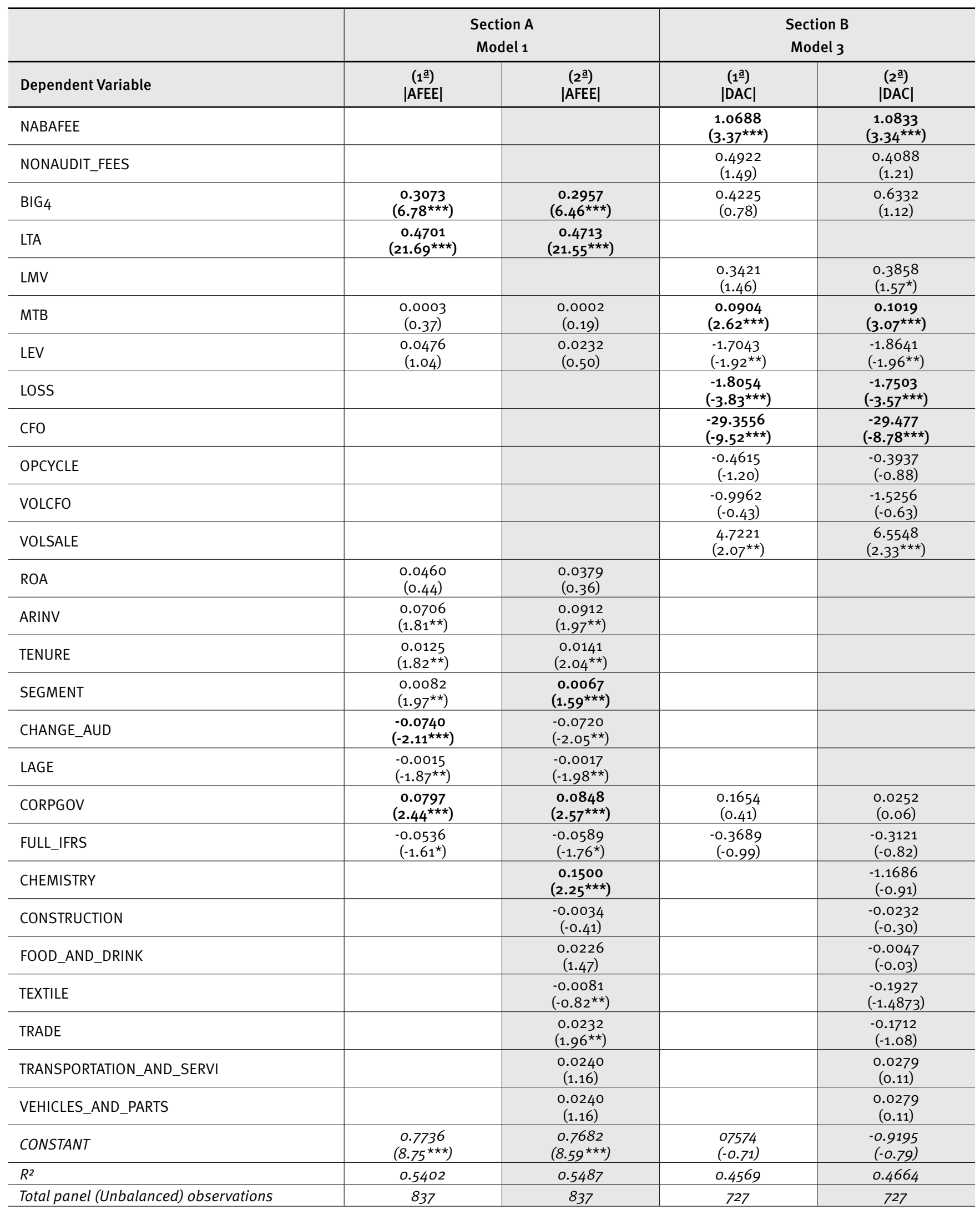

Note: ***, **, *, significant at $1 \%, 5 \%$, and $10 \%$ 
The R2 was satisfactory in all cases. However, we also carried out additional tests (not shown in the tables) to provide further evidence of the robustness of the statistics of the estimated models: i) Jarque-Bera normality test (JB), which indicated that the residuals were normally distributed; ii) variance inflation factor test (VIF), which showed there was no problem of multicollinearity; and iii) Breusch-Godfrey test (BG), showing no autocorrelation of the residuals.

\section{CONCLUSIONS}

This study investigated the relationship between audit fees and earnings management, as a proxy of audit quality in the Brazilian market. We responded to the research question by using a sample of 300 firms listed on the BM\&FBovespa over a period of four years, for which it was possible to identify the amount paid to the auditors, using data gathered from the Economatica ${ }^{\circledR}$ database and the website of the Brazilian Securities Commission (CVM).

We analyzed the regressions with the aim of supporting or refuting the hypothesis that audit firms that charge less for their service tend to be more relaxed regarding earnings management by their client companies. The results indicate that this hypothesis cannot be rejected.

The main contribution of this study is the possibility of stating that abnormal audit fees are related to abnormal discretionary accruals in the Brazilian capital market, or put another way, that more aggressive earnings management occurs predominantly among firms that pay less than expected for audit services. This study evidences the perception of risk by the audit firms and how this is reflected in the abnormal fees charged.

Exhibit 4 summarizes the main findings.

\section{Exhibit 4. Main findings}

Confirmation of the expected positive relationship between abnormal audit fees and discretionary accruals.

Confirmation of the expected positive relationship between nonaudit fees and discretionary accruals, but the results are not significant.

Confirmation of the expected positive relationship between the variable $\mathrm{BIG}_{4}$ and the amount paid to the auditor.

Confirmation of the expected negative relationship between the cash flow of the audited company and earnings management.

The results of this study have implications for regulators, such as the CVM, whose mission is to protect investors and facilitate capitalization of companies in Brazil. Independent auditing plays a fundamental role in both the capital and financial markets. The results also have implications for the members of the audit committee and senior management in general in their negotiation of audit fees. Although it may be tempting for managers to contract an auditor willing to accept a low fee, they must realize that audit firms have a cost structure, and that abnormally low fees could mean that auditors will cut corners in performing their services. This could negatively impact the audit quality and lead to an analysis of the financial statements that is more permissive of earnings management.

Likewise, the results of this study are relevant to financial analysts in their judgment of the quality of earnings when making investment recommendations. Companies that pay lower than expected audit fees might not be receiving the proper care to prevent risks of poor quality of the earnings reported.

The main limitation of this study is that it focuses on large listed companies only; future studies could include unlisted firms and/or smaller companies. Future studies could also focus on types of earnings management, such as to reduce the variability of earnings (income smoothing) or to make the results look worse than they really are so as to increase the chances of showing strong recovery in subsequent periods (taking a bath).

\section{REFERENCES}

Ashbaugh, H., Lafond, R., \& Maythew, B. (2003). Do nonaudit services compromise auditor independence? Further evidence. The Accounting Review, 78(3), pp. 611-639.

Asthana, S. C., \& Boone J. (2012). Abnormal audit fee and audit quality. Auditing: A Journal of Practice \& Theory, 31(3), 1-22. doi: http:// dx.doi.org/10.2308/ajpt-10294

Barros, A. J. O., \& Lehfeld, N. A. S. (2000). Fundamentos de metodologia científica (2ed.). São Paulo, SP: Makron Books.

Braunbeck, G. (2010). Determinantes da qualidade das auditorias independentes no Brasil (Tese de doutorado em Controladoria e Contabilidade, Universidade de São Paulo).

Bryan, D. B., \& Mason, T. W. (2016). Extreme CEO pay cuts and audit fees. Advances in Accounting, Incorporating Advances in International Accounting, 33, 1-10. doi: http://dx.doi.org/10.2308/ajpt-10294

Choi, J.-H., Kim, C. F., \& Zang, Y. (2010). Audit office size, audit quality, and audit pricing, Auditing: A Journal of Practice \& Theory, 29(1), 7397.

Deangelos, L. (1981). Auditor independence, 'low balling', and disclosure regulation. Journal of Accounting and Economics, 3(2), 113-127. doi: http://dx.doi.org/10.1016/0165-4101(81)90009-4

Defond, M. L., Raghunandan, K., \& Subramanyam, K. R. (2002). Do nonaudit service fees impair auditor independence? Evidence from going concern audit opinions. Journal of Accounting Research, 40(4), 12471274. doi: 10.1111/1475-679X.00088 
Eshleman, D., \& Guo, P. (2013). Abnormal audit fees and audit quality: New evidence. Retrieved from http://aaahq.org/AM2013/abstract. cfm?submission ID=688. doi: 10.1007/s11573-014-0709-5

Firth, M. (1997). The provision of nonaudit services by accounting firms to their audit clients. Contemporary Accounting Research, 14, 1-21. doi: 10.1111/j.1911-3846.1997.tboo524.x

Francis, J. (1984). The effect of audit firm size on audit prices. Journal of Accounting and Economics, 6 (2), 133-151. doi: http://dx.doi. org/10.1016/0165-4101(84)90010-7

Gupta, P. P., Krishnan, G. V., \& Yu, W. (2012). Do auditors allow earnings management when audit fees are low? Retrieved from http://ssrn.com/ abstract=1836829. doi: http://dx.doi.org/10.2139/ssrn.1836829

Hallak, R. T. P., \& Silva, A. L. Da (2012). Determinantes das despesas com serviços de auditoria e consultoria prestados pelo auditor independente no Brasil. Revista. Contabilidade e Finanças, 23(60), 223-231. doi: http://dx.doi.org/10.1590/S1519-70772012000300007

Hay, D. C., Knechel, W. C., \& Wong, N. (2006). Audit fees: A metaanalysis of the effect of supply and demand attributes. Contemporary Accounting Research, 23(1), 141-191. doi: 10.1506/4XR4-KT5V-E8CN$91 \mathrm{GX}$

Junjian, G., \& Dan, H. (2015). Audit fees, earnings management and litigation risk: Evidence from Japanese firms cross-listed on U.S. markets. Academy of Accounting \& Financial Studies Journal, 19(3), 125-139.

Kinney, W. R., \& Libby, R. (2002). Discussion of the relation between auditors' fees for nonaudit services and earnings management. Accounting Review, 77, 107-114. doi: 10.1506/4XR4-KT5V-E8CN-91GX
Kothari, S. P., Leone, J., \& Wasley. C. (2005). Performance matched discretionary accrual measures. Journal of Accounting and Economics, 39(1), 163-197. doi: 10.1506/4XR4-KT5V-E8CN-91GX

Larcher, D., \& Richardson, S. (2004). Fees paid to audit firms, accrual choices, and corporate governance. Journal of Accounting Research, 42(3), 625-658. doi: 10.1111/j.1475-679X.2004.to1-1-00143.x

Martinez, A. L. (2013). Earnings management in Brazil: A survey of the literature. Brazilian Business Review (English Edition), 10(4), 1-29. doi: http://dx.doi.org/10.15728/bbr.2013.10.4.1

Porta, R. La, Lopez-Florencsio, S., Shleifer, A., \& Vishny, R. W. (1997). Legal determinants of external finance. The Journal of Finance, 52(3), 1131-1150. doi: http://onlinelibrary.wiley.com/ doi/10.1111/j.1540-6261.1997.tb02727.x/abstract

Porta, R. La, Lopez-Florencsio, S., Shleifer, A., \& Vishny, R. W. (1998). Law and finance. Journal of Political Economy, 106(6), 1113-1155.

Richardson, R. J. (2010). Pesquisa social: Métodos e técnicas (3nd ed., 11. reimpr.). São Paulo, SP: Atlas.

Sankaraguswany, S., \& Whisenant, S. (2009). Pricing initial audit engagements: Empirical evidence following public disclosure of audit fees [Working paper]. National University of Singapore and University of Houston.

Sinumic, D. A. (1980). The pricing of audit services: Theory and evidence. Journal of Accounting Research, 18(1), 161-190.

Stanley, J. D. (2011). Is the audit fee disclosure a leading indicator of clients' business risk? Auditing: A Journal of Practice \& Theory, 30(3), 157-179. doi: http://dx.doi.org/10.2308/ajpt-10049

Watts, R., \& Zimmerman, J. (1986). Positive accounting theory. New Jersey, USA: Prentice Hall. 